8 Barton AC. Plasma iron and trace element status in neuroleptic induced akathisia. MSc Thesis, University of Aberdeen, 1988.

9 Norusis MJ. SPSSX Advanced Statistics Guide. New York: McGraw-Hill, 1985.

10 Bland J, Altman D. Statistical Methods for assessing agreement between two methods of clinical measurement. Lancet 1986;i:307-10.

11 Schooler NR, Kane JM. Research diagnoses for tardive dyskinesia. Arch Gen Psychiatry 1982;39:486-7.

12 Yehuda S, Youdim MBH. Brain iron deficiency: Biochemistry and behaviour. In: Youdim MBH, ed. Topics in neurochemistry and neuropharmacology Vol 2. London: Taylor and Francis, 1988.

13 Barnes T, Braude W. Akathisia variants and tardive dyskinesia. Arch Gen Psychiatry 1985;42:874-78.

14 Ben-Shachar D, Youdim MBH. Neuroleptic induced dopamine receptor supersensitivity and tardive dyskinesia may involve altered iron metabolism. Br J Pharmacol
1987;90:95.

15 Campbell WG, Raskind MA, Gordon T, Shaw CM. Iron pigment in the brain of a man with tardive dyskinesia. $A m$ J Psychiat 1985;142:364-5.

16 Hunter R, Blackwood W, Smith MC. Neuropathological findings in three cases of persistent dyskinesia following phenothiazine medication. J Neurol Sci 1968;7:263-73.

17 Csernansky JG, Holman CA, Bonnet KA, Grabowsky K, King R, Hollister LE. Dopaminergic supersensitivity at distant sites following induced epileptic foci. Life Sci 1983;32:385-90.

18 Ben-Shachar D, Jacobowitz D, Youdim MBH. Dopamine D2 receptor modulation by brain non-haem iron. Br J D2 receptor modula

19 Cadet JL, Lohr JB, Jeste DV. Free radicals and tardive dyskinesia. Trends Neurosci 1986;9:107-9.

20 Dexter DT, Jenner P, Marsden CD. Oxyferriscorbone elevates the total iron content of blood but not brain. Movement Disorders 1989;4:176-82.

\section{A note on Jacob Augustus Lockhart Clarke}

I have in another brief communication summarised the prodigious anatomical and clinical investigations of Lockhart Clarke whose name is known to students of medicine as the originator of the description of the nucleus intermediolateralis and column of grey matter in the spinal cord. His personal history is not without interest.

He was born in London in 1817, but was educated in France until the age of 13 . He followed his grandfather and brother into medicine, studying at Guy's and St Thomas' hospitals. It appears he did not graduate at the University of London, but was made a Licentiate of the Society of Apothecaries in 1842 and entered general practice. Clarke was a retiring, quiet and modest man described by contemporaries as "of noble independence, honest and just and intellectually keen". He later recommenced his studies at St George's and became MRCS (Eng) in 1860.

Clarke lived with his mother in Pimlico, and it was here that he engaged in his meticulous anatomical studies of the spinal cord and brain. He used spirits of wine and turpentine as fixatives. He distinguished the lateral from the medial cuneate (or "restiform") nucleus, and identified the nucleus intermediolateralis and the "posterior vesicular column"' now known as Clarke's column. He experimented with techniques for preserving histological sections and devised the trick of mounting them in balsam.

He provided an early account of syringomyelia and also published clinical papers on hysterical paroxysms, epilepsy, and the treatment of neuralgias by iodine. His anatomical researches were chronicled in a remarkable number of papers in the Philosophical Transactions of the Royal Society and other distinguished journals. However, recognition evaded him until he was made an FRS in 1854 and in 1864 was awarded their gold medal. In 1867 he was elected an honorary Fellow of the King's and Queen's College of Physicians in Ireland. Ironically it was only after obtaining a degree from St Andrews in
1869 that he was elected MRCP after examination. The Censors' Board resolved:

"to recommend him to the College for admission to Examination under the dispensing Clause". Permission was granted by Comitia on 24 July 1871 (annals RCP, vol 30: $p$ 186) and he was examined on the Practice of Medicine, The Principles of Public Health, and Psychological Medicine and approved on 26 July (p 192). He was elected member by Comitia on 27 July (p 193). The 'Dispensing Clause in his case was probably clause XVI of the ByeLaws.' On the Practice of Medicine, etc was one of two written papers; it appears he was excused 'On Medical Anatomy and on the Principles of Medicine' which three of the other four candidates had to sit at that time. When and where any of them confronted the three viva voce examinations required under clause XIV is not mentioned.

It reflects more on the Royal College than on Clarke that he was not made a Fellow: his name does not appear in Munk's roll. He left general practice in 1870-71 and was appointed to the Hospital for Epilepsy and Paralysis where he worked with a small private practice and little other income until his death. He suffered a severe attack of pleurisy in 1870 and in 1879 his health gradually failed. He was attended in his last illness by Hughlings Jackson and Stephen Mackenzie. The Medical Times and Gazette, 31 January 1880 (p 138) records: "Many friends would have been glad of the privilege of serving him, but he was, though kind hearted and generous, very reserved, and few knew of his illness. He passed away quietly in the first hour of 25 January, 1880."

1 Clarke JAL. Researches into the structure of the Spinal Cord (1850). Philos Trans Roy Soc London 1851;141:607-22. 2 Pearce JMS. A note on the work of Clarke of Clarke's Column. J Neurol Neurosurg Psychiatry 1990; (in press).

I am indebted to Mr Alan J Clark, Librarian at the Royal Society and to $\mathrm{Mr}$ Geoffrey Davenport, Librarian at the Royal College of Physicians for biographical data and references.

JMS PEARCE 